\title{
Analysis of gene polymorphisms TGFa rs 1058213 to cleft lip cases with or without a non-syndrome cleft palate in Riau Malay Ethnic
}

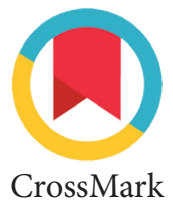

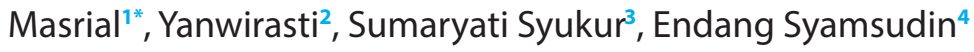

\section{Abstract}

Objective: This study aims to determine the role of gene polymorphism TGFa rs 1058213 in cases of cleft lip with or without cleft palate nonsyndrome in the Riau Malay tribe.

Material and Methods: DNA extraction of venous blood and polymorphism TGFa rs 1058213 was assessed using the Restriction Fragment Length Polymorphism-PCR (RFLP-PCR) working method and followed by sequencing. Genotyping SNP rs1058213 in the TGFa gene was performed by the RFLP-PCR method in control and CLP NS patients. The data was assessed using the test statistic premises T-test difference test.

Results: The total sample size included 68 samples consisting of 34 CLP NS samples and 34 control samples. The cases of CLP NS occurred more in men than women, 20 cases (59\%) and 14 cases (14\%), respectively. Conclusion: There was no significant difference between TGFa rs 1058213 gene polymorphisms in CLP NS and controls in the Riau Malay tribe.
${ }^{1}$ Department of Biomedicine, Faculty of Medicine, Andalas University, Padang, Indonesia

${ }^{2}$ Department of Anatomy, Faculty of Medicine, Andalas University, Padang, Indonesia

${ }^{3}$ Department of Chemistry, Faculty of Mathematics and Natural Sciences, Andalas University, Padang, Indonesia

${ }^{4}$ Department of Oral and Maxillofacial Surgery, Faculty of Dentistry, Padjadjaran University, Bandung, Indonesia

*Corresponding to: Masrial, Department of Biomedicine, Faculty of Medicine, Andalas University, Padang, Indonesia drg.masrial.spbm@gmail.com

Received: 20 June 2017

Revised: 31 January 2018

Accepted: 19 February 2018

Available online: 1 April 2018

Keywords: Cleft lip, Malay Ethnic, TGFa

Cite this Article: Masrial, Yanwirasti, SyukurS, Syamsudin E. 2018. Analysis of gene polymorphisms TGFa rs 1058213 to cleft lip cases with or without a non-syndrome cleft palate in Riau Malay Ethnic. Journal of Dentomaxillofacial Science 3(1): 32-36. D0I: 10.15562/jdmfs.v3i1.498

\section{Introduction}

Cleft lip, with or without a cleft palate, is a congenital defect that is still very often encountered and is a congenital defect in the most commonly seen on facial areas. Patients with cleft lip, with or without cleft palate, have some problems with the condition, such as aesthetic problems, food intake, speech and psychosocial problems. The incidence of congenital malformations ranges from 1:700 to 1:1000 births. Asia is the highest with 1:500 births, Africa is around 1:2000 births, and in Indonesia it is estimated to be around 1:700 births. Gorlin pointed out that the prevalence of non-syndrome cleft lip occurs 1 to 2 per 1000 births and it depends on the geographic location of the incidence. ${ }^{1-3}$

Cleft lip and palate are more common in men than women, whereas cleft palates are more common in women. The male/female ratio is 1.5-1.59:1 for cleft lip, 1.98-2.07:1 for cleft lip and palate, and 0.72-0.74:1 for cleft palate. ${ }^{2}$

Etiology of deformities cleft lip with or without a non-syndrome cleft palate (CLP NS) is caused by many factors that are the interaction between genetic factors and environmental factors. Genetic factors and/or environmental factors are suspected of having a role in the pathogenesis of CLP NS. Previous research has revealed that genes and environmental factors can act independently or in combination. Nutrition imbalances, such as vitamin B deficiency, folic acid, zinc ( $\mathrm{Zn}$ ), and vitamin A hypervitaminosis, have been reported as risk factors for cleft lip and cleft palate. Likewise, teratogenic substances such as cigarettes, pesticides, and other chemicals (alcohol, drugs) are also risk factors. Infectious diseases such as syphilis, rubella virus, cytomegalovirus, herpes, toxoplasma, and HIV are also reported to play a role. ${ }^{4}$

The TGFa gene is the first identified gene to play a role in the occurrence of CLP NS abnormality. This gene is a member of the epidermal family of growth factors. This gene plays a role in coding protein growth factor and secretion of proteins expressed in the palatal tissue. Several studies have proven not to find the role of TGFa in the case of CLP NS although there are also other studies that find the role of TGFa in different races. From several studies, TGF gene polymorphisms a rs 1058213 and rs 166975 have a significant role in the case of CLP NS. ${ }^{5}$

Research on the races of Maryland USA, Taiwan, Singapore and Korea found an association between the occurrence of cleft lip and non-syndrome palate with TGFa. The haplotype analysis showed significant results on the derivatives of the mother but not from the father. This study shows a relationship between gene and environmental interactions in mothers who smoke and consume alcohol. TGFa is known to play a role in the process of forming the palate. Several studies have found a significant relationship between TGFa with the occurrence of cleft lip and palate. ${ }^{5}$ 
Based on this background, this study will analyze whether there is a difference in polymorphism of TGFa rs 1058213 between a CLP NS sufferer and a normal person in Riau Malay.

\section{Material and Methods}

This study was conducted on humans and the material used was venous blood. Before conducting the study, ethical approval was obtained from the Research Ethics Committee of the Faculty of Medicine, University of Riau.

The study population consisted of patients suffering from or diagnosed with congenital abnormalities of cleft lip and palate. The participants were males and females with ethnic Malay Riau original Riau who came to polyclinic oral surgery Ibnu Sina Hospital, Pekanbaru and RSUD Arifin Achmad Pekanbaru.

The study sample is part of the population that meets the inclusion and exclusion criteria. Controls were taken from people who did not suffer from cleft lip, no ethnic melayu Riau native background and had no family history from cleft lip or palate. The number of samples taken was based on a $90 \%$ confidence level and $80 \%$ test power assuming that approximately 1 in 700 Indonesians suffer from cleft lip. While the difference of the proportion of writers set by $20 \%$ of the calculation using the formula above obtained the minimum sample size is 34 samples for CLP NS cases and 34 samples for controls.

The method of sampling is done in a consecutive manner where samples are taken sequentially. Each patient diagnosed with a congenital aberration is calculated as a sample with inclusion and exclusion criteria until the amount is met. This research collects data on TGFa rs 1058213 polymorphism with genotyping SNP rs1058213 on TGFa gene done using the restriction fragment length polymorphism PCR (RFLP-PCR) method. The PCR reaction has a total

Table 1 Characteristics of research CLP NS cases based on age and gender

\begin{tabular}{|c|c|c|c|c|c|}
\hline \multirow{2}{*}{\multicolumn{2}{|c|}{ Variables }} & \multicolumn{2}{|c|}{ CLP NS } & \multicolumn{2}{|c|}{ Control } \\
\hline & & n (34) & $\%$ & n (34) & $\%$ \\
\hline \multicolumn{6}{|l|}{ Age: } \\
\hline & 0 - 1 year & 10 & 29 & 5 & 15 \\
\hline & 1 - 5 years & 8 & 24 & 6 & 18 \\
\hline & 5 - 10 years & 7 & 21 & 8 & 24 \\
\hline & 10 - 20 years & 7 & 21 & 10 & 29 \\
\hline & $>20$ years & 2 & 6 & 5 & 15 \\
\hline \multicolumn{6}{|l|}{ Gender : } \\
\hline & Male & 20 & 59 & 15 & 44 \\
\hline & Female & 14 & 41 & 19 & 56 \\
\hline
\end{tabular}

volume of $25 \mu \mathrm{L}$ consisting of $0.2 \mu \mathrm{M}$ deoxynucleoside triphosphates (dNTPs); $100 \mathrm{ng}$ genomic DNA; 1.25 U HotStarTaq DNA Polymerase and its buffer solution; and $1.5 \mu \mathrm{M}$ primary forward rs1058213-F ( 5' - GGAT T C CA G GCTATATAT T TC - 3 ') and $1.5 \mu \mathrm{M}$ reverse primer rs10582131-R (5'-GACTGGTCCCCCTTTCATGG-3'). PCR was performed under the following conditions: initial denaturation at $95^{\circ} \mathrm{C}$ for $5 \mathrm{~min}$, followed by 35 cycles of a series of processes comprising denaturation at $94^{\circ} \mathrm{C}$ for $1 \mathrm{~min}$, annealing at $55^{\circ} \mathrm{C}$ for 30 seconds, and elongation at $72^{\circ} \mathrm{C}$ for 30 seconds. The PCR process concludes with the final elongation stage at $72^{\circ} \mathrm{C}$ for 10 minutes. The PCR product is 771 base pairs (bp). Furthermore, it is conducted based on the sequence method aimed to determine the polymorphism system and the nucleotide change from the sample set of PCR result. Sequencing analysis results from bioinformatics are done qualitatively with the following stages; blast, to find out the validity of the results of sequencing analysis using blast on NCBI; multiple alignment, a sequencing DNA sequences with DNA derived from GenBank data.

Genomic DNA was isolated from a blood sample of $300 \mu \mathrm{L}$ using the GB100 Geneaid Genomic DNA mini kit (Blood/cultured cell). DNA isolation was performed in accordance with the kit procedure which consisted mainly of the sample preparation stage, cell lysis stage, DNA binding stage, leaching stage, and the elution stage of DNA. The purity of DNA isolation is checked by using NanoDrop with the results attached to the attachment. After the process of editing, coding, processing, and cleaning, the data was computationally processed to observe the polymorphism of the TGFa gene using a frequency table and to see the difference of variables between the 2 groups using a T-test.

\section{Results}

The total sample size was 68 samples consisting of 34 CLP NS samples and 34 control samples. The cases of CLP NS occur more in men than women with 20 cases (59\%) and 14 cases (14\%), respectively. Of the patients within the CLP NS sample, the lowest age was 4 months and the highest age was 32 years. The highest number of patients were aged $0-1$ years (10 cases, 29\%) and the lowest number of patients were more than 20 years old ( 2 cases, $6 \%$ ), table 1.

\section{TGF gene analysis a rs 1058213}

The primer used to recognize SNP gene TGFa rs 1058213 was constructed using bioinformatics software Geneious version 7.0.6. A RFLR-PCR method was used to recognize SNP TGFa rs 1058213. 
Table 2 Primary and Restriction Enzymes for RFLP-PCR gene TGFa rs 1058213

\begin{tabular}{|c|c|c|c|c|c|}
\hline $\begin{array}{l}\text { Primary } \\
\text { Name }\end{array}$ & Primary Sequence & DNA Fold & $\begin{array}{c}\text { Size of Product } \\
\text { PCR }\end{array}$ & $\begin{array}{c}\text { Restriction } \\
\text { Enzymes }\end{array}$ & Result of RFLP-PCR \\
\hline TGFAHinfI-F & $\begin{array}{l}\text { TGFAHinfl-F } \\
\left.\text { Sequence (5' to } 3^{\prime}\right) \text { : GGATTCCAGGCTATATATTTC } \\
\text { Type: Primer } \\
\text { Length: } 21 \\
\text { created by: primer3 } \\
\% \text { GC: } 38.1 \\
\text { Tm: } 50.9 \\
\text { Hairpin Tm: None } \\
\text { Self Dimer TT: None }\end{array}$ & & $771 \mathrm{bp}$ & $\begin{array}{c}\text { HinfI } \\
\left(\mathrm{G}^{\wedge} \mathrm{ANTC}\right)\end{array}$ & $\begin{array}{l}\text { Alel CC: } 771 \text { bp } \\
\text { Alel CT: } 771 b p+582 b p+ \\
189 \text { bp } \\
\text { Alel TT: } 582 \text { bp + } 189 \text { bp }\end{array}$ \\
\hline TGFAHinfI-R & $\begin{array}{l}\text { TGFAHinfl-R } \\
\text { Sequence (5' to } 3^{\prime} \text { ): GACTGGTCCCCCTTTCATGG } \\
\text { Type: Primer } \\
\text { Length: } 20 \\
\text { created by: primer3 } \\
\% \text { GC: } 60.0 \\
\text { Tm: } 60.0 \\
\text { Hairpin Tm: None } \\
\text { Self Dimer Tm: None }\end{array}$ & & & & \\
\hline
\end{tabular}
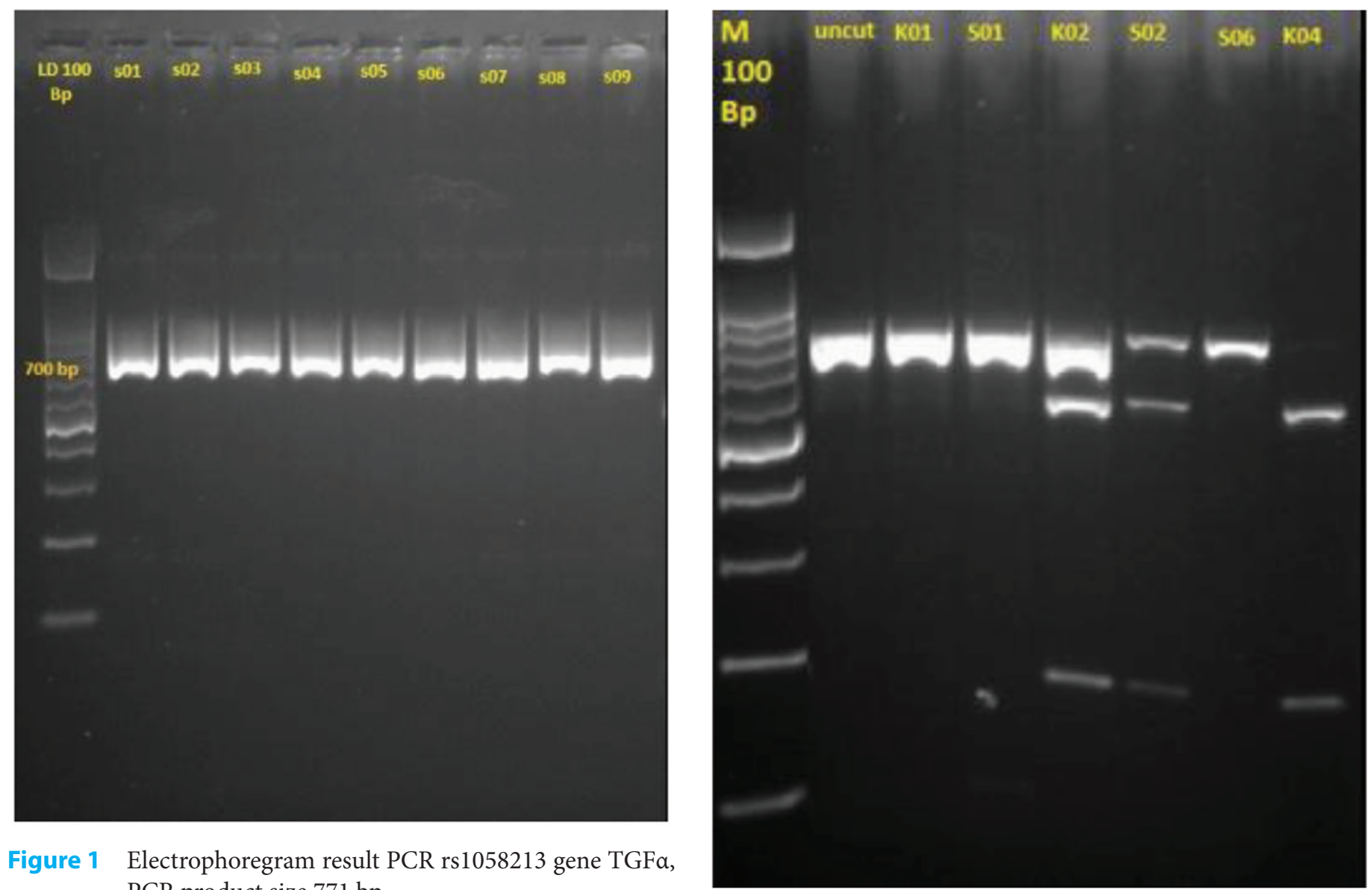

Figure 1 Electrophoregram result PCR rs1058213 gene TGFa, PCR product size $771 \mathrm{bp}$

Figure 2 Electrophoregram product restriction PCR rs1058213 with enzyme Hinf I 
Table 3 Results RFLP-PCR gene TGFa rs 1058213

\begin{tabular}{lccccc}
\hline \multirow{2}{*}{ SNP } & & \multicolumn{2}{c}{ CLP NS } & \multicolumn{2}{c}{ Control } \\
\cline { 3 - 6 } & Allele & N & $\%$ & N & $\%$ \\
\hline \multirow{2}{*}{ rs1058213 } & TT & 15 & 44 & 20 & 59 \\
& CC & 2 & 6 & 5 & 15 \\
\multirow{2}{*}{ Total } & CT & 17 & 50 & 9 & 26 \\
\hline
\end{tabular}

Table 4 Differences in TGFa rs 1058213 polymorphism results between CLP NS and control group

\begin{tabular}{lccccc}
\hline \multirow{2}{*}{ Mutation } & \multicolumn{3}{c}{ Case } & \multicolumn{3}{c}{ Control } & p \\
\cline { 2 - 6 } & $\mathbf{N}$ & \% & N & $\%$ & \\
\hline Yes & 19 & 55.9 & 14 & 41 & \\
No & 15 & 44.1 & 20 & 59 & 0.166 \\
Total & 34 & 100 & 34 & 100 & \\
\hline
\end{tabular}

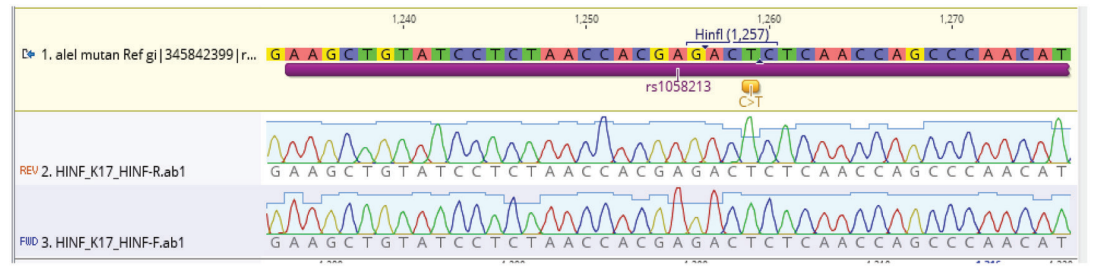

Figure 3 Alignment of control case sequencing results with SNP motif TGFa rs 1058213

The result of primary constructions for TGFa rs 1058213 can be seen in the table 2 .

\section{Primer didesain dengan bantuan software}

The PCR results were electrophoresed using a gelose of $1.5 \%$ which contained gelRed DNA colour and was visualized with GelDoc BioRad.

Figure 1 shows the result of the main sequence of TGFaHinfI-F $5{ }^{\prime}$ to $3^{\prime}$ GGATTCCAGGCTATATATTTC and TGFaHinfIR 5 ' to 3' GACTGGTCCCCCTTTCATGG with a product size of PCR $771 \mathrm{bp}$.

Based on the above results, both primary strands meet the criteria of a good primer. A further restriction was performed on several CLP NS and control samples using the restriction enzyme Hinf I. Restriction results were observed with electrophoresis using $2 \%$ agarose gel containing Gel DNA dye.

Figure 2 shows the electrophoregram interpretation of restriction results of rs1058213 with Hinf enzyme I. If only one DNA band of $771 \mathrm{bp}$ (not truncated) is obtained, the sample has a wildtype TT allele, if two DNA bands of $582 \mathrm{bp}$ and 189 bp are obtained, the sample has a CC allele (Homozygote mutants), if three DNA bands of $771 \mathrm{bp}, 582 \mathrm{bp}$ and $189 \mathrm{bp}$ are obtained, the sample has a CT allele (heterozygote mutant). The results can be seen in table 3 .

The RFLP-PCR results in the CLP NS group found that 19 people had TGFa rs 1058213 snp polymorphisms. There were homozygous mutations in 2 people (6\%) and heterozygous mutations in 17 people (50\%). Polymorphism was also found in the control group consisting of homozygous mutations in 5 people (15\%) and heterozygous mutations in 9 people (26\%). The results are summarized in table 4.

In addition to using a RFLP-PCR method to recognize snp TGFa rs1058213, direct DNA sequencing was conducted so that the allele was visible figure 3 . The sample sequencing results were analyzed bioinformatically with contig and BLAST (Basic Local Alignment Search Tool). Splitting the sequenced result data was done using the Genios Sample Alignment Process K17 (Confirmation with restriction result). Based on figure 3 , it is evident that the control sample K17 does not undergo polymorphism.

Table 4 shows the statistical test of the occurrence of TGF $\alpha$ rs 1058213 polymorphism in CLP NS and control groups in the Malay tribe Riau. There is no significant differences between patients with CLP NS and patients in the control group $(\mathrm{p}=0.166)$. However, in the CLP NS group, the TGFa rs 1058213 polymorphism is more prevalent than the control group (55.9\%:44.1\%).

\section{Discussion}

This study analyzes the relationship between allele polymorphisms of the TGFa gene that is in the allele rs 1058213 in CLB NS Malay Riau. In our data, we found that the CLB NS is more common in men than in women with 20 cases (59\%) in men and 14 cases (14\%) in women.

TGFa is a gene that plays a role in human growth factor. This gene has long been indicated to be involved in the occurrence of cleft lip cases. Lidral et al. ${ }^{6}$ from Iowa city in 2005, said TGFa is an influential gene in the formation of cleft lip. In another study, Rajion et al. ${ }^{7}$ found that TGFa is present in the process of facial development and there is a significant relationship between these genes and the occurrence of cleft lip and palate.

In this study, we tested the allele polymorphism of TGFa rs 1058213. Unlike some studies conducted, the research on TGFa rs 1058213 in CLP NS and control patients in this Riau Malay tribe cannot be declared statistically influential against the occurrence of the CLP NS. Although no significant differences were found between TGFa rs 1058213 polymorphisms, the affect of TGFa on control of lip and palate clearance occurrences 
in the Riau Malay tribe cannot yet be concluded. Further research is needed on all TGFa alleles to draw the conclusion whether TGFa has an effect on the occurrence of CLP NS cases in the Riau Malay tribe.

\section{Conclusion}

This study showed that there is not enough evidence that the TGFa rs 1058213 gene has a role in the incidence of CLP NS cases in the Riau Malay tribe. Nevertheless, further research is needed on all TGFa alleles to draw the conclusion that TGFa has an effect on the occurrence of CLP NS case in the Riau Malay tribe. In addition, it is also necessary to consider research with a larger sample of CLP NS patients in the Riau Malay tribe.

\section{Acknowledgement}

The study did not receive any financial support.

\section{Conflict of Interest}

The authors report no conflict of interest.

\section{References}

1. Verloes A. Updated diagnostic criteria for charge syndrome: a proposal. Am J Med Genet A 2005;133: 306-308.

2. Mossey PA, Little J, Munger RG, et al. Cleft lip and palate. Lancet 2009;374: 1773-1785.

3. Wahyuni A, Yunus M, Ruslin M. The difference uses of panoramic photo and cbct evaluation of the gnathoplasty surgery outcome. J Dentomaxillofac Sci 2017;2: 110-113.

4. Malik NA. Textbook of oral and maxillofacial surgery. JP Medical Ltd; 2012. p. 615-618.

5. Sull JW, Liang KY, Hetmanski JB, et al. Evidence that TGFA influences risk to cleft lip with/without cleft palate through unconventional genetic mechanisms. Human Genetics 2009;126: 385-394.

6. Lidral AC, Moreno LM. Progress toward discerning the genetics of cleft lip. Current Opinion Pediatrics 2005; 17: 731.

7. Rajion ZA, Alwi Z. Genetics of cleft lip and palate: a review. Malay J Med Sci 2007;14: 4-9.

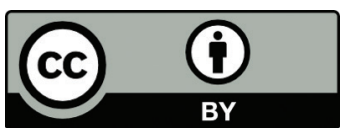

This work is licensed under a Creative Commons Attribution 